\title{
Çam kese böceği (Thaumetopoea wilkinsoni Tams) zararının kızılçam (Pinus brutia Ten.) büyümesi üzerindeki etkisinin beş yıllık sonuçları
}

\author{
Neşat ERKAN (Orcid: 0000-0003-1800-4926) ${ }^{1 *}$ \\ ${ }^{1}$ Bursa Teknik Üniversitesi, Orman Fakültesi, BURSA \\ *Sorumlu yazar/Corresponding author: nesaterkan@yahoo.com, Geliş tarihi/Received: 04.06.2018, Kabul tarihi/Accepted: 11.06.2018
}

$\ddot{O} z$

Çam kese böceği (Thaumetopoea wilkinsoni Tams.) ülkemizde çoğunlukla Akdeniz Bölgesinde ve özellikle kızılçamda, zaman zaman da sedir ve karaçam gibi diğer ibreli ormanlarda larva döneminde ağaçların ibrelerini yiyerek zarar yapmaktadır. Geçici süreliğine de olsa üretim organlarını kaybeden ağaçların büyüme faaliyetleri olumsuz etkilenmektedir. Diğer yandan böcek zararı, ibrelerin bir yıldan daha uzun sürede yenilenmesi nedeniyle ağaçların büyümesi üzerinde sadece cari yılda değil, daha sonraki yıllarda da etkili olabilmektedir. Yine zararın etkisi, böcek zararının sadece bir yıl veya devam eden yıllarda da olup olmamasına göre önemli ölçüde değişebilmektedir. Bu çalışmada çam kese böceğinin kızılçam büyümesi üzerine cari yıldaki ve cari yılı aşan etkisinin ortaya konulması amaçlanmıştır. Çalışma, Antalya yöresinde iki farklı deneme alanında 5 yıl boyunca yürütülmüştür. Başlangıçta böcek zararı sonucu \% 40 ve üzeri oranda yaprak kaybına uğrayan ağaçlar işaretlenmiş, daha sonraki yıllardaki yaprak kaybı durumları da izlenerek, eklemeli toplam yaprak kaybı ölçülmüştür. Yine yaprak kaybına uğrayan bu ağaçların, kontrol ağaçlarına kıyasla beş yıllık süre içinde toplam çap ve hacim büyümesi kaybı hesaplanmıştır. Çalışma sonucunda beş yıllık eklemeli toplam yaprak kayıp oranı ile toplam çap ve hacim büyüme kaybı arasında anlamlı ilişki tespit edilmiş olup, bu ilişkiyi yansıtan doğrusal regresyon denklemleri ortaya konmuştur. Ayrıca ağaçlardaki yine beş yıllık toplam kese adedi ile yaprak kayıp oranı arasındaki ilişki incelenmiş, ancak bu ilişkinin iki deneme alanı için de anlamlı olmadığı ortaya konmuştur.

Anahtar kelimeler: Kızılçam (Pinus brutia Ten.), çam kese böceği (Thaumetopoea wilkinsoni), ibre kaybı, böcek zarar1, büyüme kaybı

\section{Five-year results of the impact of pine processionary moth (Thaumetopoea wilkinsoni Tams) on the growth of Turkish red pine (Pinus brutia Ten.)}

\begin{abstract}
Pine processionary caterpillar (Thaumetopoea wilkinsoni Tams.) larvae cause defoliation by eating leaves mainly in Turkish red pine, but sometimes in cedar and Crimean pine forests in Mediterranean Region of Turkey. The growth rate of the trees are adversely affected by the defoliation, even it is temporary. On the other hand, defoliation may have an effect on tree growth not only in the current year but also over years due to the renewal of the leaves in every two years. Moreover, the reduction in growth rate may change considerably depending on whether the defoliation occurred only one year or more in following years. In this study, we aimed at determining the over-years effect of defoliation in Turkish red pine forests. The research was conducted in two different sites for five years in Antalya region. At the beginning, trees defoliated in more than $40 \%$ were marked and observed in the following five years for their defoliation, and total defoliation rate was calculated by adding up defoliation rate in all years. Total diameter (Dbh) and volume loss of all defoliated trees were measured for five years and comparing to control trees. As a result, significant relationship between added total defoliation rate and total Dbh and volume growth lose for five years were determined and linear regression equations were calculated. Additionally, the relationship between added total defoliation rate and the total number of nests of pine processionary moth for five years was investigated, however, this relationship was not significant in both sites.
\end{abstract}

Keywords: Turkish red pine (Pinus brutia Ten.), pine processionary caterpillar (Thaumetopoea wilkinsoni), defoliation, insect damage, growth loss

To cite this article (Atıf): ERKAN, N .(2018). Çam kese böceği (Thaumetopoea wilkinsoni Tams) zararının kızılçam (Pinus brutia Ten.) büyümesi üzerindeki etkisinin beş yıllık sonuçları, Ormancılık Araştırma Dergisi, 5(2), 135-142.

DOI: https://doi.org/10.17568/ogmoad.430501 


\section{Giriş}

Ormanın tanımı değişik kaynaklarda farklı şekillerde yapılmakla birlikte ekolojik açıdan orman; "ağaçlarla birlikte aralarında karşılıklı etki ve ilişkiler bulunan diğer bitkiler, fauna, mikroorganizma, toprak, hava, su ve iklim gibi diğer doğa faktörlerinin birlikte oluşturdukları bir sistem, bir doğal ünite" olarak tanımlanmaktadır (Çepel, 1978). Bu tanımdan anlaşılacağı gibi orman sadece ağaçlardan oluşmamakta, çok sayıda canlı barındırmakta ve böcekler de orman kavramı içinde sayılarak ağaçlarla olan karşılıklı ilişkileri (menfi veya müspet) ormanda cereyan eden doğal bir olgu olarak kabul edilmektedir.

Diğer böceklerde olduğu gibi çam kese böceği (ÇKB) de kendisine yaşam alanı olarak daha çok çam ormanlarını, bazen de sedir ormanlarını seçmekte, toprakta kışlamakta ve larva döneminde beslenmesini gece ibreleri yiyerek yapmaktadır (Can ve Özçankaya, 2003). Özellikle kış ve ilkbaharda yoğunlaşan beslenme zamanlarında ağaçlarda değişik oranlarda yaprak kaybına neden olmaktadır. Zaman zaman bu yaprak kayb1 \%100'e ulaşabilmektedir. ÇKB zararı özellikle genç ormanlarda etkili olmaktadır ve sonrasında odun zararlısı böceklerin gelmesi durumunda zaman zaman ağaçların ölümüne bile sebep olabilmektedir. Bilimsel çalışmalar göstermiştir ki ÇKB popülasyonu meşcere yapısı, güneşlenme durumu ve bakı gibi faktörlere bağlı olarak değişmektedir. Ayrıca bir meşcere içinde de ÇKB'nin tercihi düzenli bir dağılış göstermemekte; genetik yap1, toprak verimliliği, derinliği ve yapısı, güneşlenme ve rüzgâr durumuna bağlı olarak ağaçtan ağaca değişim arz etmektedir (Buxton, 1983; Özkazanç, 2002; Avc1, 2000; Akkuzu ve ark., 2009; Régolini ve ark., 2014; Parlak ve ark., 2018).

Zararın fazla olduğu yerlerde orman adeta yangın geçirmiş gibi yapraksız ağaçlardan oluşan ölü meşçere görüntüsüne bürünebilmektedir. Bununla birlikte çoğunlukla bu zarar, orman içinde sıklığ ve yayılışı farklı olmak üzere münferit ağaçlarda olmaktadır. Genellikle böcek zararının sona erdiği dönemden (iklim şartlarına ve denizden yükseltiye göre değişmekle beraber çoklukla Haziran başı) başlayarak ağaç yapraklarını yenilemekte ve yeni ibre oluşturmaktadır (Lambers ve ark., 1998). Bir başka deyişle çam kese böceği çoğunlukla ağacın ölümüne neden olmamaktadır ve ağaç aynı yıl vejetasyon mevsimi sonuna kadar yeni ibrelerini oluşturarak eski görünümünü kazanmaktadır. Ancak ülkemizdeki ormanc1 meslek kamuoyu çam kese böceği zararına uğramış ağaçların gerek ölmüş ağaç görüntüsü veren vahim durumunun etkisiyle gerekse bu ağaçlarda büyük oranda büyüme kaybının olması (Buxton, 1983; Battisti ve ark., 1998; Hódar ve ark., 2004; Durkaya ve ark, 2009; Carus, 2009; Erkan, 2011) nedeni ile duruma müdahale etme ihtiyacı duymakta ve değişik yöntemlerle çam kese böceği ile mücadeleye girmektedir.

Ormanları işletmekte olan Orman Genel Müdürlüğü (OGM) konuya duyarlılıkla yaklaşarak belli ölçüde müdahil olmakta, ÇKB ile değişik yöntemlerle (mekanik, biyoteknik, kimyasal, biyolojik vb.) mücadele etmektedir. Genel Müdürlüğün her yıl gerçekleştirdiği böcekle mücadele harcamalarının önemli bir kısmı ÇKB'ye karşı yapılmaktadır. Örneğin 2017 yılında ülke genelinde ÇKB ile mücadele için 2,8 milyon TL harcanmış ve bu miktar genel böcekle mücadele harcamalarının \% 34,5'lik kısmını oluşturmuştur (Anonim, 2018).

ÇKB'nin çoğunlukla zarar yaptığ 1 tür olan kızılçam 5,6 milyon hektarlık yayılış alanı ve 9,53 milyon $\mathrm{m}^{3} / \mathrm{y}$ 1l odun üretimi (toplam ibreli odun üretiminin \% 62'si) ile Türkiye ormancılığında önemli ağaç türlerinden biridir (OGM, 2018). Çam kese böceği ağaçların ölümüne neden olmamakla birlikte, Genel Müdürlüğün böcekle hangi düzeyde mücadele edeceğini belirlemeye esas olmak üzere ağaçlardaki büyüme kaybı miktarı şeklinde oluşan zararın bilinmesine ihtiyaç vardır. Ağaçlarda ÇKB'nin neden olduğu büyüme kayıplarını kestirmeye yönelik yapılan çalışmaların (Buxton, 1983; Battisti ve ark., 1998; Hódar ve ark., 2004; Çatal, 2011; Erkan, 2011) çoğunda böcek zararının olduğu cari yıl ile ağaç büyümesi arasında olan ilişkiler incelenmiştir. Oysa bilindiği gibi ibrelilerde ÇKB tarafından yenen ibrenin tam olarak oluşması bir yıldan uzun sürmektedir (örneğin kızılçamda 2 y1l sürmekte ve ibreler 2 yılda bir yenilenmektedir). Dolayısıyla böcek zararının beklenen etkisi bir yıldan daha uzun olmaktadır.

Nitekim Lemoine (1977) genç Pinus maritima ormanında yaptığ 1 bir çalışmada \% 100 yaprak kaybına uğramış bir ağacın normal büyüme seviyesine ulaşabilmesi için 3 yıl geçmesi gerektiğini ortaya koymuştur. Ayrıca üst üste birden fazla yıl ve değişik oranlarda böcek zararına uğrayan ağaçlardaki büyüme kaybının nasıl olacağının da bilinmesine ihtiyaç bulunmakta olup bu ayrıntıyı ele alan yeterince çalışma bulunmamaktadır. Erkan (2011), bu çalışma ile aynı deneme alanlarında yürüttüğü çalışmada, \% 40 ve üzeri oranda yaprak kaybına uğramış genç kızılçam ağaçlarının, oranları deneme alanlarına göre değişmekle birlikte, kontrol ağaçlarına göre cari yıldaki bir yıllık çap büyümesi kaybının \% 55'e kadar, hacim büyümesi kaybının ise $\% 44$ 'e kadar çıkabildiğini ortaya koymuştur. 
$\mathrm{Bu}$ çalışmada, genç kızılçam ormanlarında ÇKB'nin birden fazla yıl arka arkaya ve değişik oranlarda zarar yapmasıyla oluşan artım kayıpların genel anlamda incelenmesi amaçlanmıştır. İki deneme alanında beş yıl boyunca yapılan ölçmelerle ÇKB zararı sonucu oluşan yaprak kayıp oranları ile çap ve hacim büyümesi arasındaki ilişki incelenmiştir. Ayrıca böcek larvalarının ağaç üzerinde oluşturduğu kese sayısı ile zarar miktarı arasındaki ilişki analiz edilmiştir.

\section{Materyal ve Yöntem}

Çalışma Batı Akdeniz Bölgesinde, Antalya yakınındaki genç kızılçam meşcerelerinden alınan $50 \mathrm{~m} \times 50 \mathrm{~m}=2.500 \mathrm{~m}^{2}$ büyüklüğündeki iki farklı deneme alanında 2000-2004 yılları arasında yürütülmüştür. Başlangıçta üç deneme alanı alınmış, ancak üçüncü deneme alanında sadece birinci yıl ÇKB zararı olmuş, diğer yıllar herhangi bir zarar olmadığ 1 için söz konusu alan bu çalışmada değerlendirme dışı bırakılmıştır. Kızılçam yaprakları iki yılda bir yenilenmesi nedeni ile belli bir yıldaki yaprak kaybı yeni yaprakların oluşması için gerekli olan iki yıl boyunca büyüme üzerinde etkili olabilmektedir. Bu nedenle deneme alanları seçilirken meşcerelerin OGM kayıtlarında son iki yılda ÇKB zararı görmemiş olmasına dikkat edilmiştir. Deneme alanlarına ilişkin bilgiler Tablo 1'de verilmiştir.
Deneme alanlarının bulunduğu yerde tipik Akdeniz iklimi hüküm sürmekte, yazları kurak ve sıcak, kışları ise 1 lık ve nemli geçmektedir. Uzun yıllar ortalama yağış $1.091 \mathrm{~mm} /$ yıl olup bu yağışlar daha çok kışın gerçekleşmektedir. En düşük ortalama sıcaklık Ocak ayında $5^{\circ} \mathrm{C}$ ve en yüksek ortalama sıcaklık ise Temmuz ayında $34^{\circ} \mathrm{C}$ olarak gerçekleşmiştir.

Araştırma, deneme alanlarında tek ağaç ölçmelerine dayalı olarak yapılmıştır. Her bir deneme alanında orta galip ağaçlardan tepesi $\% 40$ ve üzeri oranda zarar görmüş 32 ağaç ve kontrol ağacı olarak 32 ağaç olmak üzere toplam 64 ağaç belirlenmiş, bu ağaçlar metal plakalar ile numaralandırılmıştır. Burada dört yıl boyunca ağaçlarda yaprak kayıp oranlarının \% 40 ve üzeri olması şartı her yıl için aranmamış, zarar görmüş ağaçların daha sonraki yılların en az birinde zararın tekrarlanması yeterli kabul edilmiştir. Ancak başlangıçta zarar görmüş olarak belirlenen ağaçlardan bazıları sonraki yıllarda hiç zarar görmedikleri için deneme dışı bırakılmıştır. Bu işlem neticesinde 24 zarar görmüş ve 24 kontrol ağacı olmak üzere her deneme alanında 48 ağaç değerlendirilmiştir. Zarar gören her bir ağaç, büyüme bakımından karşılaştırılmak üzere özellikleri (çap, boy, tepe çatısı ve aralık mesafe) itibariyle benzer olan bir kontrol ağacı ile eşleştirilmiştir.

Tablo 1. Deneme alanları ve bazı özellikleri

Table 1. Test sites and some associated properties

\begin{tabular}{|c|c|c|c|c|c|}
\hline $\begin{array}{l}\text { Deneme } \\
\text { alanlar1 }\end{array}$ & $\begin{array}{l}\text { Meşcere yaşı } \\
\text { (2004 y1lında) }\end{array}$ & $\begin{array}{l}\text { Orta çap } \\
\quad(\mathrm{cm})\end{array}$ & $\begin{array}{l}\text { Bonitet endeksi (m) } \\
\text { (30 yaşında üst boy) }\end{array}$ & $\begin{array}{l}\text { Orta boy } \\
\text { (m) }\end{array}$ & Deneme alanı koordinatları \\
\hline Asar 1 & 16 & 14,71 & 21 & 9,62 & $\begin{array}{c}36 \text { S } 0300133 \\
\text { UTM } 4105970\end{array}$ \\
\hline Asar 2 & 17 & 16,04 & 22 & 10,28 & $\begin{array}{l}36 \text { S } 0300612 \\
\text { UTM } 4105726\end{array}$ \\
\hline
\end{tabular}

ÇKB tarafından yiyim zararına uğramış ağaçların yaprak kayıp oranları her yıl yiyimin tamamlanmasını müteakip nisan ayı sonunda yapılan yerinde gözlem ile \% cinsinden belirlenmiştir. Gözlemler sağlıklı olması için her defasında tek bir kişi tarafından, tepeyi oluşturan yeşil dokunun ne kadarının kaybolduğu şeklinde yapılmıştır. Bir ağaç için eklemeli toplam yaprak kayıp oranı (\%), her bir yıl için ayrı ayrı toplanarak hesaplanmıştır. Ağaç çapları mm duyarlıklı çap ölçerle, ağaç boyları ise Haglöf Vertex III Hipsometer aleti kullanılarak cm duyarlıklı olarak ölçülmüştür. 2004 yılı vejetasyon sonu itibariyle, zarar görenlerin ve kontrol ağaçlarının her birinden artım burgusu kullanılarak kuzey ve güney yönlerden iki adet artım kalemi alınmıştır. Artım kalemleri üzerinden PREISSER DIGI-MET ölçme aleti kullanılarak yıllık halka kalınlıkları 0,01 mm duyarlıklı olarak ölçülmüştür.

Bu çalışmada büyümeye esas parametre olarak çap büyümesi (artımı) alınmış ve yıllık çap büyümesi olarak karşılıklı iki artım kaleminden ölçülen ilgili yıl halka kalınlığının toplamı şeklinde hesaplanmıştır. Daha sonra çap ve boya dayalı olarak hacim büyümesi (artımı) hesaplanmıştır. Hacmin hesaplanmasında Usta (1991) tarafından geliştirilen ve Formül-1 ile verilen çift girişli hacim denklemi kullanılmıştır. Formül 2 ve 3 ile de sırasıyla toplam çap büyümesi kayıp oranı ve toplam hacim büyümesi kayıp oranı hesaplanmıştır. Bunun için her bir zarar gören ağaç ve kontrol ağacı için periyodik 
(beş yıllık) çap ve hacim artımları başlangıçtaki çap ve hacim değerlerine bölünerek artım oranları hesaplanmış, daha sonra kontrol ağaçları ile zarar gören ağaçların artım oranları farkı hesaplanmıştır. Beş yıllık eklemeli toplam yaprak kayıp oranı ise her y11 \% cinsinden gözlenen yaprak kayıp oranları toplanarak elde edilmiştir (Formül 4).

$\operatorname{Ln}\left(V_{i}\right)=\left[\ln (-2,007746621)+1,67681754 * \ln \left(d_{i}\right)+\right.$ $\left.0,845096118^{*} \ln \left(h_{i}\right)\right]^{*} 1,007987$

$$
\begin{aligned}
& T d d l_{i}=\left[\left(\sum d d k_{i j}\right) / d k_{i 0}\right]-\left[\left(\sum d d z_{i j}\right) / d z_{i 0}\right] \\
& T d v l_{i}=\left[\left(\sum d v k_{i j}\right) / v k_{i 0}\right]-\left[\left(\sum d v z_{i j}\right) / v z_{i 0}\right] \\
& T l_{i}=\sum l l_{i j}
\end{aligned}
$$

$V_{i}: i$. ağacın hacmi $\left(\mathrm{dm}^{3}\right) ; d_{i}: i$. ağacın göğüs çap1 $(\mathrm{cm}) ; h_{i}: i$ ağacın boyu (m); Tdd $l_{i}: i$. ağacın toplam çap büyümesi kayıp oranı $(\%) ; d d k_{i j}: i$. kontrol ağacının $j$. yıldaki çap $\operatorname{artım} 1(\mathrm{~cm}) ; d k_{i 0}: i$. kontrol ağacının başlangıçtaki çapı $(\mathrm{cm}) ; d d z_{i j}: i$. zarar görmüş ağacın $j$. yıldaki çap $\operatorname{artımı~}(\mathrm{cm}) ; d z_{i 0}: i$. zarar görmüş ağacın başlangıçtaki çapı $(\mathrm{cm}) ; T d v l_{i}: i$. ağacın toplam hacim büyümesi kayıp oranı $(\%) ; d v k_{i j}: i$. kontrol ağacının $j$. yıldaki hacim $\operatorname{artımı~}\left(\mathrm{dm}^{3}\right) ; v k_{i 0}$ : $i$. kontrol ağacının başlangıçtaki hacmi $\left(\mathrm{dm}^{3}\right) ; d v z_{i j}$ : $i$. zarar görmüş ăgacın $j$. yıldaki hacim $\operatorname{artım1~}\left(\mathrm{dm}^{3}\right)$; $v z_{i 0}: i$. kontrol ağacının başlangıçtaki hacmi $\left(\mathrm{dm}^{3}\right)$; $T l l: i$. ağacın eklemeli toplam yaprak kayıp oranı $(\%) ; l l_{i j}: i$. ağacın $j$. yıldaki yaprak kayıp oranı (\%)

Çalışmada ölçümün yapıldığg beş yıllık dönem için ve her bir ağaç için periyodik çap ve hacim artım yüzdeleri hesaplanmış, zarar gören ağaçlar bu bakımdan kendileri ile eşleştirilmiş olan kontrol ağaçları ile karşılaştırılarak periyodik çap ve hacim büyüme kayıp oranları belirlenmiştir. Hesaplanan bu oranlar aynı dönem içerisinde her yıl her bir ağaç için yıllık olarak belirlenen yaprak kayıp

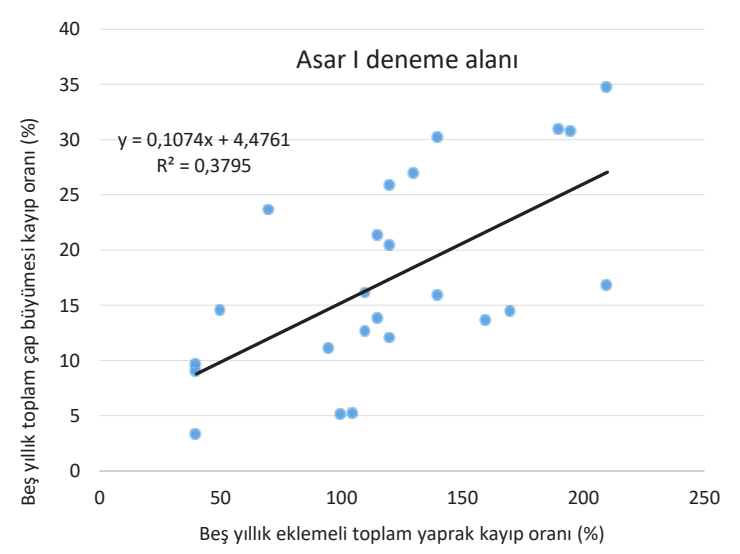

oranlarının toplamı ile ilişkiye getirilmiştir.

\section{Bulgular}

\section{1. Çap büyümesi - yaprak kaybı ilişkisi}

$\mathrm{Bu}$ çalışmada beş yıllık dönem içerisinde ÇKB tarafından her yıl değişik oranlarda yaprak kaybına uğramış ağaçların eklemeli toplam yaprak kaybına bağlı olarak bu dönemdeki toplam çap büyümesi oranındaki değişim incelenmiştir. Araştırmanın yapıldığı her iki deneme alanında da yaprak kayıp oranı arttıkça kontrol ağaçlarına göre ÇKB'den zarar gören ağaçlarda çap büyümesi kayıp oranı da belirgin bir şekilde artmaktadır (Şekil 1). Yaprak kayıp oranına göre çap büyümesi kayıp oranının kestirilmesine ilişkin doğrusal regresyon denklemleri Şekil 1'de verilmiştir. Yapılan varyans analizi sonuçlarına göre regresyon modelinin verilere uygunluğu \% 99 güven düzeyinde anlamlı bulunmuştur (Tablo 2). Ancak belirtme katsayıları $\left(\mathrm{R}^{2}\right)$ Asar I ve Asar II deneme alanlarında sirasi ile 0,38 ve 0,40 olarak bulunmuştur. Belirtme katsayılarının çok yüksek bulunmayışı noktaların diyagramda regresyon eğrisi etrafında geniş bir alanda serpilmiş olmasından, bir başka deyişle çap büyümesi üzerinde etkisi olan ve bu denemede kontrol altına alınamayan tesadüfi faktörlerden kaynaklanmaktadır.

\subsection{Hacim büyümesi - yaprak kaybı ilişkisi}

Çap ve hacim arasındaki kuvvetli ilişkiden dolayı hacim büyümesi ile yaprak kaybı arasındaki ilişki çap büyümesininkine benzer bulunmuştur (Şekil 2). Yine burada beş yıl boyunca eklemeli toplam yaprak kayıp oranı arttıkça beş yıllık periyodik hacim artışındaki kayıp oranı da anlamlı bir şekilde artmaktadır. Şekil 2'de her iki deneme alanı için regresyon denklemleri verilmiş olup belirtme katsayıları deneme alanı I ve II için sırasıyla 0,35

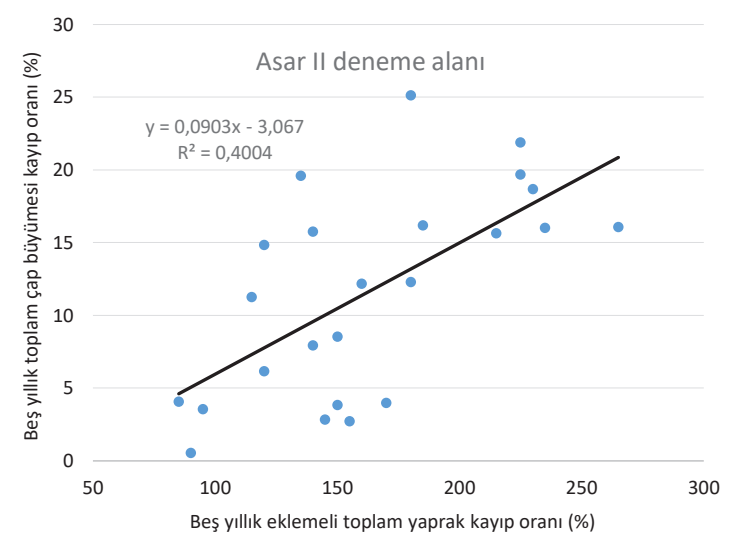

Şekil 1. Beş yıllık eklemeli toplam yaprak kayıp oranına göre çap büyümesi kayıp oranının değişimi Figure 1. Relationship between five-year total diameter (Dbh) growth loss and total defoliation rate 
Tablo 2. Beş yıllık toplam çap büyümesi kayıp oranını, toplam yaprak kayıp oranına dayalı olarak kestirmeye yönelik regresyonda varyans analizi sonuçları

Table 2. ANOVA results in regression to estimate five-year total diameter (Dbh) growth loss based on total defoliation

\begin{tabular}{lcccc}
\hline \multicolumn{5}{c}{ Asar I deneme alanı } \\
\hline Model & Serbestlik derecesi & Kareler ortalamas1 & $F$ & $P$ \\
\hline Regresyon & 1 & 690,465 & 13,454 & $0,001^{* *}$ \\
Hata & 22 & 51,319 & & \\
Toplam & 23 & & & \\
\hline \multicolumn{5}{c}{} \\
Regresyon & 1 & Asar II deneme alan1 & & \\
Hata & 22 & 457,788 & 14,692 \\
Toplam & 23 & 31,158 & & \\
\hline
\end{tabular}

Bağlı değişken: Beş yıllık toplam çap kayıp oranı (\%); Serbest değişken: Beş yıllık eklemeli toplam yaprak kayıp oranı (\%) **: \%99 güven düzeyi için fark anlamlı

ve 0,41 olarak hesaplanmıştır. Burada da yine belirtme katsayıları çap artım kaybı için hesaplandığı gibi ve benzer nedenlerle düşük hesaplanmıştır.

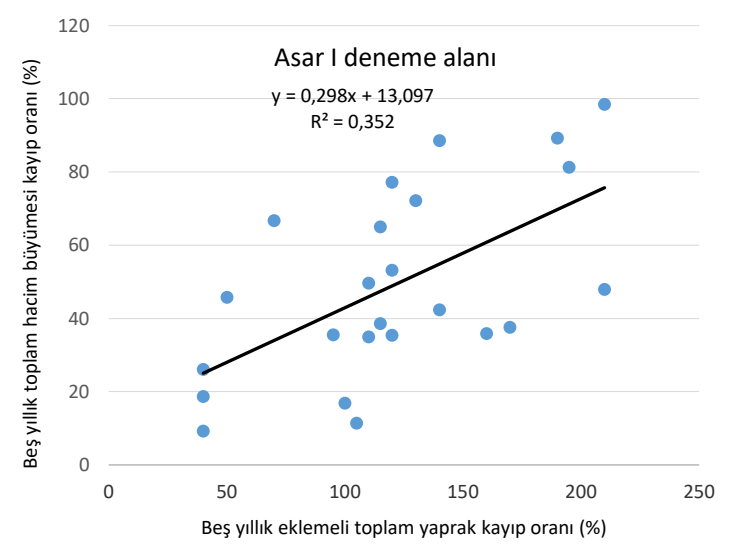

Ancak yapılan regresyonda varyans analizi sonuçları regresyon denklemlerinin $\% 98$ ve \% 99 güven düzeyinde anlamlı bulunmuşlardır (Tablo 3).

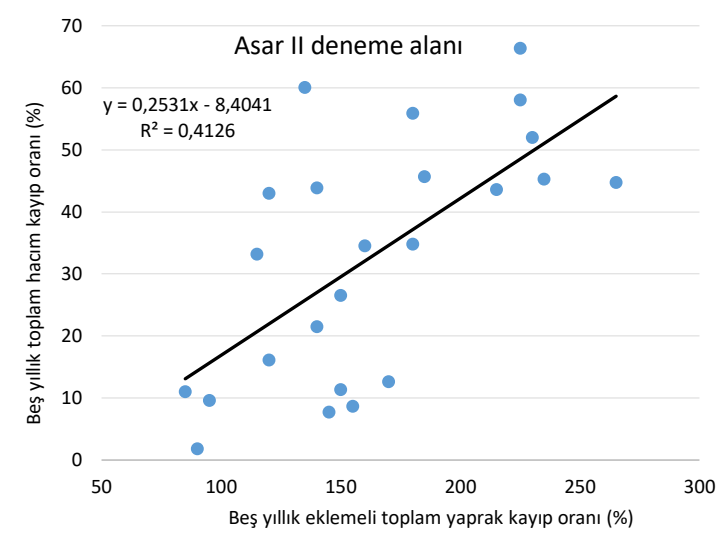

Şekil 2. Beş yıllık eklemeli toplam yaprak kayıp oranına göre toplam hacim büyümesi kayıp oranının değişimi Figure 2. Relationship between five-year total volume growth loss and total defoliation rate

Tablo 3. Beş yıllık toplam hacim büyümesi kayıp oranını yaprak kaybı oranına dayalı olarak kestirmeye yönelik regresyonda varyans analizi sonuçları.

Table 3. ANOVA results in regression to estimate five-year total volume growth loss based on total defoliation rate

\begin{tabular}{lcccc}
\hline \multicolumn{5}{c}{ Asar I deneme alan1 } \\
\hline Model & Serbestlik derecesi & Kareler ortalamas1 & $F$ & $0,002^{* *}$ \\
\hline Regresyon & 1 & 5311,555 & 11,950 & \\
Hata & 22 & 444,482 & & \\
Toplam & 23 & & & \\
\hline \multicolumn{4}{c}{ Asar II deneme alan1 } \\
\hline Regresyon & 1 & 3600,407 & 15,455 & \\
Hata & 22 & 232,965 & & \\
Toplam & 23 & & & \\
\hline
\end{tabular}

Bağlı değişken: Beş yıllık toplam hacim kayıp oranı (\%); Serbest değişken: Beş yıllık eklemeli toplam yaprak kayıp oranı (\%) **: \%99 güven düzeyi için fark anlamlı 


\subsection{Kese sayısı - yaprak kaybı ilişkisi}

ÇKB larvaları yaprak yiyimi sırasında yine kendi yaptıkları kese içinde barınmakta ve genellikle beslenmek amacıyla gece yuvadan çıkıp yiyim yapmaktadırlar. Bu bilgi ilk bakışta kese sayısı ile yaprak yiyimi miktarı arasında önemli ilişkinin olabileceğini akla getirmektedir. Çalışmamızda beş yıl boyunca her bir deneme alanı ve her bir ağaç için sayılan (cari yılda örülmüş keseler dikkate alınmıştır) kese sayılarının toplamı ile yine beş yıl boyunca ilgili ağacın eklemeli yıllık yaprak kaybı oranları bir grafik üzerine taşınmıştır (Şekil

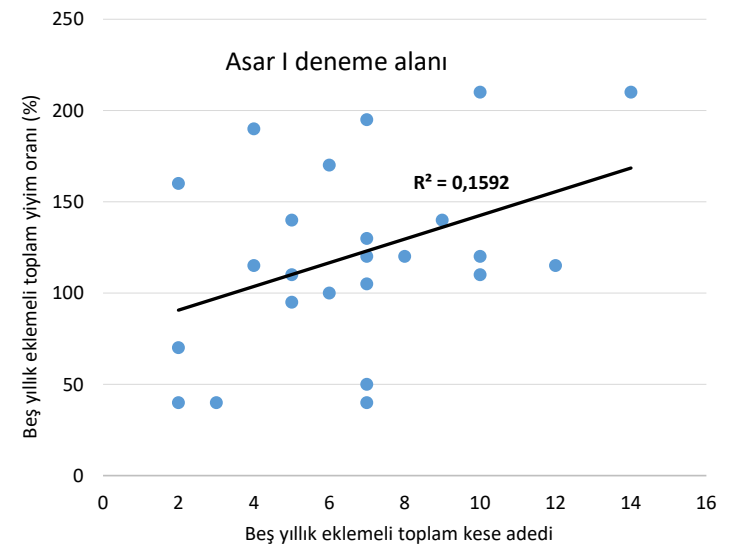

3). Şekilden de görüleceği gibi, noktalar oldukça geniş alanda serpilmiş olup toplam yaprak kayıp oranını toplam kese sayısı aracılığı ile kestirmeye yönelik geçirilen regresyon doğrusuna ait belirtme katsayıları oldukça küçük çıkmıştır. $\mathrm{Bu}$ değerler sırasıyla deneme alanı I ve II için $\mathrm{R}^{2}=0,16$ ve $\mathrm{R}^{2}=$ 0,01 olarak hesaplanmıştır. Söz konusu regresyona ilişkin varyans analiz sonuçları, her iki deneme alanında da beş yıllık toplam yaprak kayıp oranının \% 95 güven düzeyi için kese sayısına göre farklılaşmadığını, dolayısıyla toplam kese adedi aracılığı ile yaprak kayıp oranının güvenle kestirilemeyeceğini göstermiştir (Tablo 4).

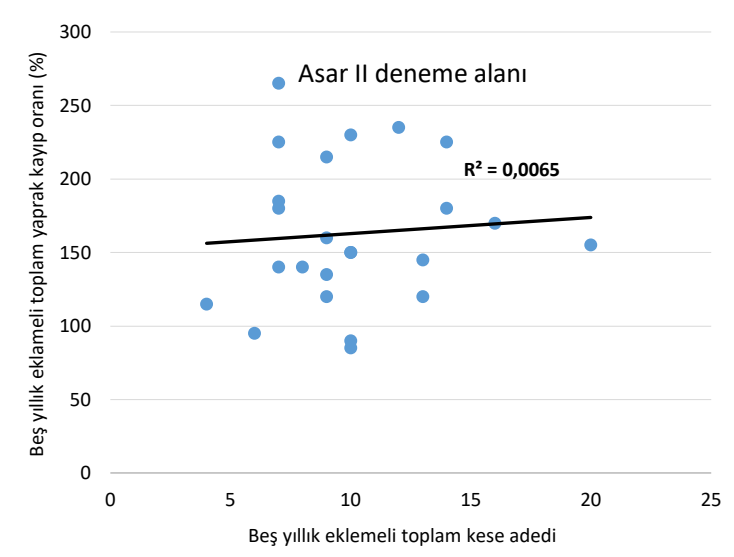

Şekil 3. Beş yıllık toplam eklemeli yaprak kayıp oranı ile toplam kese adedi arasındaki ilişki Figure 3. Relationship between five-year total defoliation rate and number of nests

Tablao 4. Beş yıllık eklemeli toplam yaprak kayıp oranını toplam kese adedine dayalı olarak kestirmeye yönelik regresyonda varyans analizi sonuçları

Table 4. ANOVA results in regression to estimate five-year total defoliation rate based on number of nests

\begin{tabular}{lcccc}
\hline \multicolumn{5}{c}{ Asar I deneme alan1 } \\
\hline Model & Serbestlik derecesi & Kareler ortalamas & $F$ & $0,053^{\text {ns }}$ \\
\hline Regresyon & 1 & 9520,473 & 4,164 & \\
Hata & 22 & 2286,143 & & \\
Toplam & 23 & & & \\
\hline & & Asar II deneme alan1 & \\
\hline Regresyon & 1 & 362,707 & 0,143 \\
Hata & 22 & 2537,869 & & \\
Toplam & 23 & & & \\
\hline
\end{tabular}

Bağlı değişken: Beş yıllık eklemeli toplam yaprak kayıp oranı (\%); Serbest değişken: Beş yıllık toplam kese adedi ns: $\% 95$ güven düzeyi için fark anlamsız

\section{Tartışma ve Sonuç}

Çam kese böceğinin (ÇKB) sebep olduğu yaprak kaybının cari yıl ağaç büyümesi üzerinde etkili olduğu, değişik ağaç türlerinde yapılan araştırma- larla ortaya konmuştur. Örneğin Jacquet ve ark. (2012), ÇKB'nin büyüme üzerine etkisini araştıran 45 çalışmayı incelemiş ve daha çok genç ormanlarda olmak üzere \% 50 oranında büyüme kaybına sebep olduğunu rapor etmiştir. Laurent-Hervouet 
(1986) çam türlerinde ÇKB zararını araştırmış ve çap artımını \% 35 oranında düşürdüğünü ortaya koymuştur. Markalas'ın (1998) 5 yaşlı Pinus pinaster ağaçlarında yaptığı çalışmada, çam kese böceği zararından bir yıl sonra sürgün biyomas miktarındaki etkisine bakmış ve bu etkinin orta zarar görmüş ağaçlarda \% 41-45 ve çok zarar görmüş ağaçlarda ise \% 54-64 oranında olduğunu ortaya koymuştur. Yine tarafımızdan yapılan bir çalışmada (Erkan, 2011) ÇKB’nin \% 40 ve üzeri oranda yaprak kaybına sebep olduğu kızılçam ağaçlarında çap ve hacim büyümesi üzerinde 0,001 anlamlılık düzeyinde etkili olduğu ve yıllık çap ve hacim büyümesini sırası ile \% 55 ve \% 44 oranlarına kadar düşürebildiği ortaya konmuştur.

$\mathrm{Bu}$ çalışmada ise ÇKB'nin sebep olduğu yaprak kaybının cari yılı aşan etkileri ile beş yıllık çalışma süresi içinde birden fazla yıl yaprak kaybına uğrayan ağaçlardaki periyodik (beş yıllık) çap ve hacim büyümesi kaybı incelenmiştir. Elde edilen sonuçlara göre, beş yıl içinde birden fazla yıl ÇKB yiyimine uğramış ağaçlarda yine bu dönemdeki çap ve hacim büyümesinin önemli düzeyde etkilendiği görülmüştür. Beş yıllık dönemdeki çap ve hacim büyümesi kayıp oranının bu dönemde yaşanan yaprak kayıp oranlarının toplamı aracılığı ile güvenli bir şekilde ve belli açıklama oranı $\left(\mathrm{R}^{2}\right)$ ile kestirilebileceği anlaşılmış ve bu amaçla kullanılabilecek denklemler Şekil 1 ve 2'de verilmiştir. Keza, Lemoine (1977), Pinus maritima'da çam kese böceği zararının büyüme üzerine etkisini araştırmış ve yaprak kaybının büyüme üzerinde cari yılı aşan etkilerinin olduğunu belirlemiş ve yaprak kaybına uğrayan ağaçların kontrole kıyasla normal büyüme hızına ancak 3. yılda ulaşabildiğini ortaya koymuştur. Aynı çalışmada yaprak kaybının üç yılın sonunda hacimde, gövde çevresinde ve boyda \% 31'lik bir azalmaya sebep olduğunu hesaplamıştır. Kanat ve ark. (2005) kızılçamda yaptıkları araştırmada ÇKB yiyim zararına uğrayan yaprak miktarının 2/3'ünü kaybetmiş ağaçların dört yılın sonunda çap büyümesini \% 21 oranında düşürdüğü sonucuna varmışlardır.

Çalışmamızda beş yıllık toplam kese sayısı ile eklemeli toplam yaprak kaybı oranı arasında anlamlı ilişki bulunamamıştır. Bunun sebebi keselerdeki larva sayılarının geniş aralıkta değişmesi (146313 adet) ve terkedilmiş boş keselerle açıklanabilir. Nitekim ÇKB larvaları yiyim aşamasında beş keseye kadar kese yapabilmekte; ayrıca daha önce yaptıkları keseyi ve ağacı terk ederek başka ağaçlara geçebilmektedirler (Can ve Özçankaya, 2003). Dolayısıyla kese sayısı ÇKB zararının şiddetini anlamaya yönelik kullanışlı bir gösterge sayılmamaktadır.
Bu çalışmadan elde edilen bilgilere dayalı olarak, arka arkaya veya aralıklarla birden fazla yıl ve değişik oranlarda ÇKB zararından dolayı oluşan eklemeli toplam yaprak kayıp oranı, ağaçta çap ve hacim büyümesi kayıp oranının belli güvenirlikte kestirilmesinde kullanılabilir. Ağaçlardaki kese sayısı ise, toplam yaprak kaybı ile yeterli ilişki göstermemesi nedeni ile ÇKB zararının önemli bir göstergesi sayılmamaktadır.

Teşekkür: $\mathrm{Bu}$ çalışmada verilerin toplanmasında Orman Genel Müdürlüğü, Batı Akdeniz Ormanc1lık Araştırma Enstitüsü Müdürlüğünün olanaklarından faydalanılmıştır. Verilerin toplanması sırasında yardımı geçen Orman Yüksek Mühendisi M. Necati Baş’a teşekkür ederim.

\section{Kaynaklar}

Akkuzu, E., Eroğlu, H., Sönmez, T., Yolası̆̆maz, H.A., Sariyıldız, T., 2009. Effects of forest roads on foliage discoloration of oriental spruce by Ips typographus, African Journal of Agricultural Research 4 (5): 468-473

Avc1, M., 2000. Investigation on structure of egg-batches, parasitism and egg laying habits of Thaumetopoea pityocampa (Den. \& Schiff.) (Lep.: Thaumetopoeidae) in various regions of Turkey, Turkiye Entomoloji Dergisi 24 (3): $167-178$

Battisti A., Longo S., Tiberi, R., Triggiani, O., 1998. Results and perspectives in the use of Bacillius thuringiensis Berl. Var. Kurstaki and other pathogens against Thaumetopoea pityocampa (Den. Et Schiff.) in Italy (Lep., Thaumetopoeidea), Anz. Schadlingskde., Pflanzenchutz, Umweltschutz 71: 72-76.

Buxton, R.D., 1983. Forest management and pine processionary moth, outlook on agriculture, No: 1, Pergamon Pres. Britain 12: 34-39.

Can, P., Özçankaya, M., 2003. Ege Bölgesi ağaçlandırma alanlarında çam kese böceği (Thaumetopoea pityocampa Schiff.) yumurta parazitoitlerinin belirlenmesi, Ege Ormancılık Araştırma Müdürlüğü, Teknik Bülten No: 22, İzmir

Carus, S., 2009. Effects of defoliation caused by the processionary moth on growth of Crimean pines in western Turkey, Phytoparasitica 37:105-114

Çatal, Y., 2011. The effects of pine processionary moth (PPM) defoliation degree on radial growth of brutian pine (Pinus brutia), African Journal of Agricultural Research, 6 (21): 4931-4936

Çepel, N., 1978. Orman Ekolojisi, İ. Ü. Orman Fakültesi 
Yayın No: 257, İstanbul

Durkaya, A., Durkaya, B., Dal, İ., 2009. The effects of the pine processionary moth on the increment of Crimean pine trees in Bartın, Turkey, African Journal of Biotechnology 8 (10): 2356-2361

Erkan, N., 2011. Impact of pine processionary moth (Thaumetopoea wilkinsoni Tams) on growth of Turkish red pine (Pinus brutia Ten.). African Journal of Agricultural Research 6 (21): 4983-4988

Hódar José, A., Zamora, R., Castro, J., Baraza, E., 2004. Feast and famine: previous defoliation limiting survival of pine processionary caterpillar (Thaumetopoea pityocampa) in Scots pine (Pinus sylvestris), Acta Oecologica, International Journal of Ecology 26: 203-210.

Jacquet, J.S., Orazio, C., Jactel, H., 2012. Defoliation by processionary moth significantly reduces tree growth: a quantitative review, Annals of Forest Science 69: 857866

Kanat, M., Alma, M.H., Sivrikaya, F., 2005. Effect of defoliation by Thaumetopoa pityocampa (Den. \& Sciff.) (Lepidoptera: Thaumetopoeidea) on annual diameter increment of Pinus brutia Ten. In Turkey, Annals of Forest Science 62: 91-94

Lambers, H., Chapin III F.S and Pons, T.L., 1998. Plant Physiological Ecology (Book), Second edition, Springer, NewYork, p. 603

Laurent-Hervouet, N., 1986. Mesure des pertes de croissance radiale sur quelques espèces de Pinus dues à deux défoliateurs forestiers., I - Cas de la processionnaire du pin en région méditerranéenne, Annals of Forest Science 43 (2): $239-262$

Lemoine, B., 1977. Contribution à la mesure des pertes de production causées par la chenille processionaire
Thaumetopoea pityocampa Schiff. au pin Maritime dans les Landes de Gascogne, Annals of Forest Science 34 (3): 205-214.

Markalas, S., 1998. Biomass production of Pinus pinaster after defoliation by the pine processionary moth (Thaumetopoea pityocampa Schiff.), Proceedings: population Dynamics, Impact and Integrated Managenet of Forest Defoliating Insects, USDA Forest Service General Technical Report, NE-274: 292-302

Anonim, 2018. Orman Genel Müdürlüğü, Orman Zararlıları ile Mücadele Dairesi Başkanlığı kayıtları, yayımlanmamış, Ankara

OGM, 2018. Orman istatistikleri, https://www.ogm.gov. tr/ekutuphane/Istatistikler/Forms/AllItems.aspx (Ziyaret tarihi: 30.05 .2018 )

Özkazanç, O., 2002. Natural enemy of Thaumetopoea pityocampa Schiff. (Lepidoptera, Thaumetopoeidae), Proceeding: Thaumetopoea pityocampa problems and their solutions in Turkish forests, 75-87, Kahramanmaraş, Turkey

Parlak, S., Özçankaya, İ.M., Batur, M., Akkaş, M.E., Boza, Z., Toprak, Ö., 2018. Determining the edge effect of pine processionary moth (Thaumetopoea pityocampa) in its horizontal distribution in the stand, Journal of Forestry Research (in press).

Régolini, M.,Castagneyrol, B., Dulaurent-Mercadal, A.M., Pioui, D., Samalens,J.C., Jactel, H., 2014. Effect of host tree density and apparency on the probability of attack by the pine processionary moth, Forest Ecology and Management 334: 185-192

Usta, H.Z., 1991. Kızılçam (Pinus brutia Ten.) ağaçlandırmalarında hasılat araştırmaları, Ormancılık Araştırma Enstitüsü, Teknik Bülten No: 219, Antalya 